\title{
Development and validation of a simple, sensitive enzyme immunoassay for quantification of androstenedione in bull plasma
}

\author{
Smrutirekha Mallick ${ }^{1 *}$, BS Bharath Kumar ${ }^{1}$, BS Prakash², Anjali Aggrawal ${ }^{1}$ and Sujata Pandita ${ }^{1}$
}

\begin{abstract}
As an alternative to radioimmunoassay a simple and highly sensitive enzyme immunoassay (EIA) was developed and validated for androstenedione quantification in plasma of Karan Fries bulls using second antibody coating technique. The wells of the microtitreplate were coated with affinity-purified goat immunoglobulin (antirabbit lgG) that binds the hormone specific antibody. The EIA was performed to analyze androstenedione directly in $40 \mu \mathrm{l}$ of bull plasma. The androstenedione standards ranged from 0.20 to $200 \mathrm{pg} / 40 \mu \mathrm{l} /$ well and the sensitivity of the assay was $5 \mathrm{pg} / \mathrm{ml}$ plasma. Serially diluted bull plasma containing high endogenous androstenedione showed good parallelism with bovine androstenedione standard curve. Intra- and inter-assay coefficients of variation (CV) were found to be 8 and 9\%, respectively. Peripheral plasma androstenedione concentrations determined in young and adult bull samples ranged between 104-990 pg/ml and 184-2040 pg/ml, respectively.
\end{abstract}

Keywords: Androstenedione, Enzyme immunoassay, Bull, Plasma, Standardisation

\section{Background}

Androstenedione is the common precursor of male and female sex hormones. Being the predominant steroid in case of young animals, measurement of androstenedione provides a useful marker of androgen biosynthesis. Several radioimmunoassay (RIA) procedures [1-4] for estimation of androstenedione were developed and standardised, however these procedures require an extraction step which entails the use of hazardous solvents. Additionally the use of a radioisotope limits the application to labs which possess license; other disadvantages include proper disposal of radioactive waste, use of expensive instrumentation and requirement of adequate lab space. Although a few enzyme immunoassay (EIA) procedures have been developed [5,6] in recent years, the direct coating of hormone specific antibody on microtitre plate employed by these procedures resulted in extensive usage of the expensive antiserum. Advantages of second antibody coating EIA technique over direct coating technique are reduced time dependent drift, less

\footnotetext{
* Correspondence: smrutip_mallick@rediffmail.com

'Dairy Cattle Physiology Division, National Dairy Research Institute, Karnal 132001, India

Full list of author information is available at the end of the article
}

expensive, high precision and sensitivity. Hence a study was designed to develop a highly sensitive and specific EIA using second antibody coating technique for androstenedione determination in bovine plasma.

\section{Methods}

Enzyme immunoassay for androstenedione

The development of a heterologous competitive ELISA for androstenedione determination was done using 96well flat bottomed polystyrene microtitre plates (Greiner Labotrechnik, Germany) using the second antibody coating technique and androstenedione-HRP as a label in unextracted bull plasma. The affinity-purified goat IgG (antirabbit IgG) was developed following the procedure of Anandlaxmi and Prakash [7]. The antiserum used in these assays was highly specific for androstenedione. Percentage cross-reaction of androstenedione antiserum with related steroids at $50 \%$ binding was determined.

\section{Preparation of hormone-free plasma and enzyme label}

For preparation of androstenedione-free plasma, blood samples were collected from aged Karan Fries cows. Plasma was separated after centrifugation of blood and 
in-order to remove traces of androstenedione, it was treated with charcoal and dextran mixture as follows:

Mixture of activated charcoal (14 g) and dextran T-70 $(1.4 \mathrm{~g})$ per $100 \mathrm{ml}$ plasma were taken and the mixture was washed with distilled water by thorough mixing, using a magnetic stirrer for overnight at room temperature. After allowing the mixture to stand for $5 \mathrm{~min}$, the supernatant was discarded and the mixture was again subjected to the washing process for three more times at $8 \mathrm{~h}$ intervals to remove all traces of suspended fine charcoal particles. Cow plasma was then added to the washed charcoal-dextran mixture and mixed thoroughly for $2 \mathrm{~h}$ at $4^{\circ} \mathrm{C}$. Then the mixture was centrifuged at $1500 \times g$ for $1 \mathrm{~h}$ at $4^{\circ} \mathrm{C}$ and the supernatant was filtered to remove suspended particles. The filtrate was again centrifuged at $5000 \times g$ for $1 \mathrm{~h}$ at $4^{\circ} \mathrm{C}$ and the supernatant was re-filtered. The plasma thus obtained was tested for androstenedione concentration in an assay. The concentration of androstenedione in this charcoal dextran stripped plasma was below detectable limit of the assay $(<5 \mathrm{pg} / \mathrm{ml})$. The androstenedione-free plasma was then stored at $-20^{\circ} \mathrm{C}$ for future use.

Horseradish peroxidase (HRP; Serva, Germany) was used for coupling to androstenedione using the mixed anhydride method [8] with modifications [9].

\section{EIA procedure}

Wells were coated with $0.63 \mu \mathrm{g}$ of goat IgG antirabbit IgG dissolved in $100 \mu \mathrm{l}$ of coating buffer $(15 \mathrm{mM}$ $\mathrm{Na}_{2} \mathrm{CO}_{3}$ and $35 \mathrm{mM} \mathrm{NaHCO}$, pH 9.6) per well of the microtitre plate. The plates were subsequently incubated overnight at $4{ }^{\circ} \mathrm{C}$. For blocking the remaining binding sites, $300 \mu \mathrm{l}$ of $1 \%$ bovine serum albumin (BSA) in phosphate buffer was added to all the wells and incubated for 40-50 min at room temperature under constant shaking. The coated plates were then washed twice with $350 \mu \mathrm{l} /$ well of washing solution $(0.05 \%$ Tween 20$)$ using an automated microtiter plate washer (Labsystem, Model: EL 50 8MS, USA). Then a two-dimensional titer determination for optimum dilution of each androstenedioneHRP conjugate and androstenedione antiserum was carried out. Antibody dilutions ranging from 1:1,000 to 1:640,000 and androstenedione-HRP dilutions of 1:5,000 to $1: 60,000$ were tested. The antibody titer of $1: 8,000$ and the androstenedione-HRP conjugate titer of 1:20,000 were found to be optimum, and $\mathrm{OD}_{450}$ of around 0.85 was achieved by using these titers. Then $\mathrm{du}-$ plicates of $40 \mu \mathrm{l}$ of unknown plasma sample or androstenedione standards prepared in charcoal-dextran treated hormone-free plasma ranging from 0.20 to $200 \mathrm{pg} / 40 \mu \mathrm{l} /$ well were simultaneously pipetted into respective wells along with $100 \mu \mathrm{l}$ of androstenedioneHRP conjugate diluted $(1: 20,000)$ in assay buffer with the aid of a dilutor dispenser. Then, $100 \mu \mathrm{l}$ of androstenedione specific antiserum diluted in assay buffer $(1: 8,000)$ was added immediately to all wells except blank by a repeat dispenser.

The plates were kept in water bath for $1 \mathrm{~h}$ at $37^{\circ} \mathrm{C}$ and thereafter incubated overnight at $4^{\circ} \mathrm{C}$. The plates were then washed four times with washing solution and incubated further in the dark for 40 min after addition of $150 \mu \mathrm{l}$ of substrate solution per well (substrate buffer: $0.05 \mathrm{M}$ citric acid, $0.11 \mathrm{M} \mathrm{Na}_{2} \mathrm{HPO}_{4}$ and $0.05 \%$ urea hydrogen peroxide: $\mathrm{pH} 4.0$ adjusted with $5 \mathrm{~N} \mathrm{HCl}$; substrate solution: $17 \mathrm{ml}$ substrate buffer plus $340 \mu \mathrm{l}$ 3,3',5,5' 'tetramethyl benzidene; $12.5 \mathrm{mg} / \mathrm{ml}$ dimethyl sulfoxide; Sigma, USA). The reaction was stopped by the addition of $50 \mu \mathrm{l} 4 \mathrm{~N} \mathrm{H}_{2} \mathrm{SO}_{4}$ and the intensity of colour was measured at $450 \mathrm{~nm}$ with a 12-channel microtitre plate reader (Model: ECIL, Microscan, India).

\section{Parallelism between androstenedione standards and endogenous androstenedione in bull plasma}

To determine the parallelism between androstenedione standards and endogenous androstenedione, plasma samples from two bulls containing high concentrations of endogenous androstenedione were serially diluted with EIA assay buffer to obtain plasma volumes of 40, $20,10,5,1.25$ and $0.63 \mu \mathrm{l}$. Parallelism was assessed between these serial dilutions of the bull plasma samples and androstenedione standards (ranging from 0.20 to $200 \mathrm{pg} / 40 \mu \mathrm{l} /$ well, prepared in assay buffer) when run in an assay.

\section{Experimental animals and blood sampling}

The experiment was conducted in the Artificial Breeding research Complex (ABRC); National Dairy Research Institute, Karnal, Haryana, India. Four adult Karan Fries bulls $(3-3.5 \mathrm{yr})$ and Four Karan Fries bull calves (8-10 months) were selected and maintained in individual bull pens, under stall-fed condition and uniform managemental practices. Five blood samples were collected from all the animals in EDTA coated tubes by jugular vein puncture at 30 minutes interval for a period of $2 \mathrm{~h}$. The samples $(5 \mathrm{ml})$ were immediately cooled in ice and centrifuged at $4^{\circ} \mathrm{C}$. The plasma obtained was stored at $-20^{\circ} \mathrm{C}$ until hormone analysis by the procedure as described below. Animal experimentation methods were approved by the Institutional Animal Ethical Committee of National Dairy Research Institute (1705/GO/ac/13/ CPCSEA Dt. 3/7/2013).

Recovery of the added androstenedione was determined by measuring androstenedione previously added to hormone free plasma. Results obtained by the developed EIA technique (un-extracted plasma) were compared with the RIA (commercially available kit) method in ether extracted plasma samples. 


\section{Statistical analysis}

All data were expressed as means \pm SEM. To assess parallelism between androstenedione standards and serially diluted bull plasma samples containing endogenous androstenedione, a non-linear regression test was performed. Pearson's correlation test was used to analyze the statistical relation between androstenedione concentrations estimated by EIA and RIA procedures. Significance was considered at $\mathrm{P}<0.05$ level if otherwise not stated.

\section{Results and discussion Assay validation}

The lowest androstenedione detection limit significantly different from zero concentration was $0.2 \mathrm{pg} / \mathrm{well} /$ $40 \mu \mathrm{l}$ plasma, which corresponded to $5 \mathrm{pg} / \mathrm{ml}$ plasma (Figure 1). To determine the possible interference of plasma with the assay sensitivity, androstenedione standards in various amounts of charcoal treated plasma (10, 20 and $40 \mu \mathrm{l})$ were run in an assay. The EIA was carried out taking duplicates of $40 \mu \mathrm{l}$ of unknown plasma samples and androstenedione standards ranging from 0.20 to $200 \mathrm{pg} /$ $40 \mu \mathrm{l} /$ well. The sensitivity of EIA in the present experiment was $5 \mathrm{pg} / \mathrm{ml}$ of plasma, while previous studies employing RIA reported the sensitivity to be $20 \mathrm{pg} / \mathrm{ml}$ [10], $300 \mathrm{pg} / \mathrm{ml}$ [11] and $8 \mathrm{pg} / \mathrm{ml}$ [4]. Peripheral plasma androstenedione concentrations determined in bull calves (104-990 pg/ml) were similar as reported by others $[12,13]$.

\section{Intra-and inter-assay precision}

The precision of the technique based on the intra- and inter-assay coefficients of variation $(\mathrm{CV})$ was found to be 8 and $9 \%$, respectively. Different plasma volumes for the EIA (viz. 10, 20 and $40 \mu \mathrm{l}$ ) did not influence the shape of the standard curve even though a slight drop in

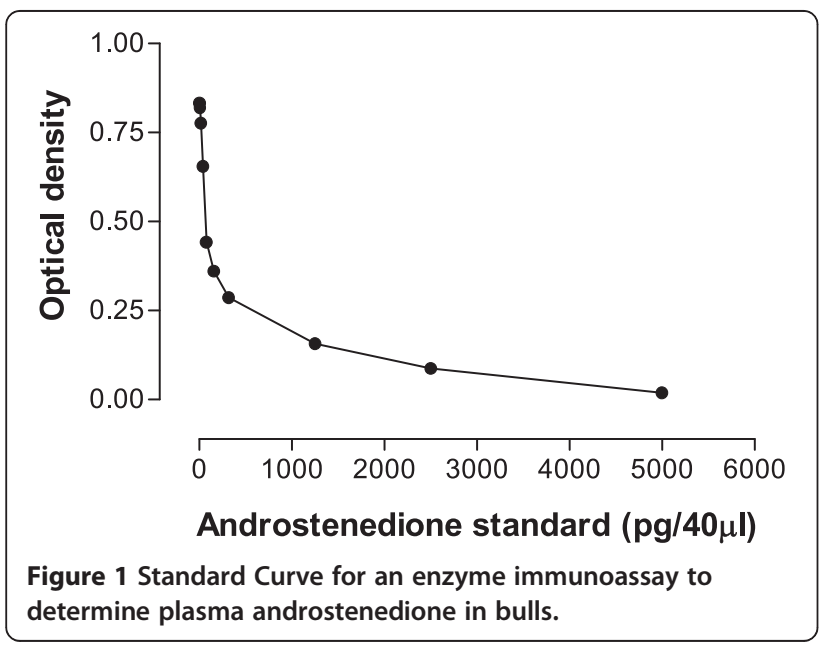

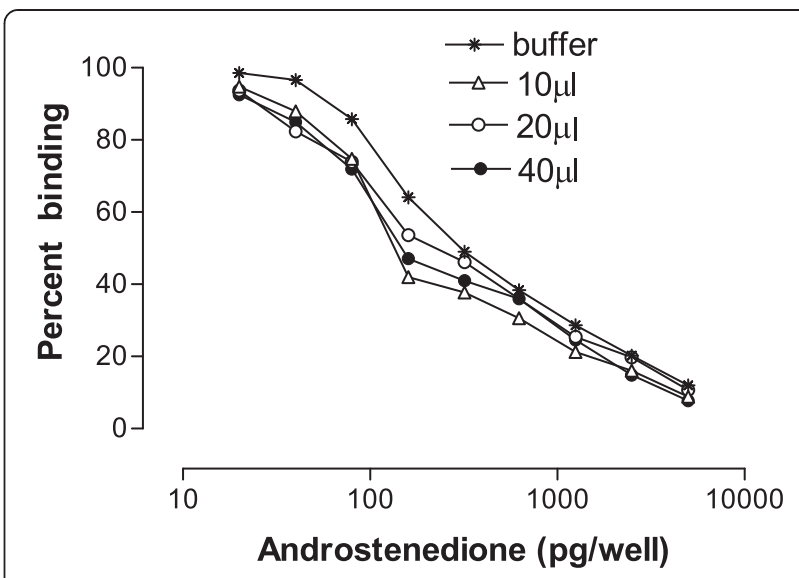

Figure 2 Androstenedione standard curve (Percent binding) as influenced by buffer and different volumes of plasma.

the $\mathrm{OD}_{450}$ was seen with higher plasma volumes (Figures 2 and 3$)$.

\section{Specificity}

The androstenedione antiserum (A1 pool 1, anti- $\Delta^{4}-6-\mathrm{HS}$ ) used in these assays was highly specific. The cross-reactivity of the anti-Androstenedione serum against different related steroids was assessed to quantify the specificity of the androstenedione antisera (Table 1).

\section{Recovery of the added hormone concentrations}

Recoveries (mean $\pm \mathrm{SE}$ ) of known amounts androstenedione previously added to androstenedione free plasma $(100,200,400,1000$ and $2000 \mathrm{pg} / \mathrm{ml})$ were $102.24 \pm 2.14$, $198.45 \pm 4.67,396.76 \pm 5.63,1006.65 \pm 8.27$ and 2009.41 $\pm 11.16 \mathrm{pg} / \mathrm{ml}$, respectively.

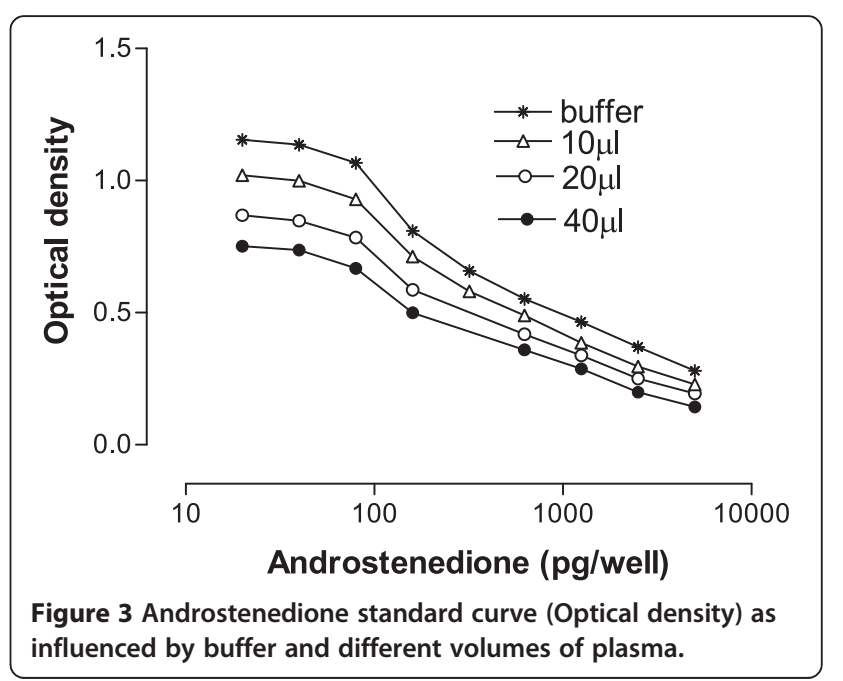


Table 1 Cross-reactivity of androstenedione antibody

\begin{tabular}{|c|c|}
\hline Steroids & Cross reaction $^{a}$ \\
\hline Androstenedione & 100 \\
\hline Androsterone & 56 \\
\hline$\Delta$-Androsten-3 $\beta$-17 $\beta$-diol & $<0.001$ \\
\hline 1,4-androstadien-17ß-ol-3-one & 0.4 \\
\hline 5-androsten-3ß-ol-17-one (dehydroisoandrosterone) & 22 \\
\hline 5a-androstan-17ß-ol-3-one (androstanolone) & 1 \\
\hline Testosterone & 1.3 \\
\hline 17a-methyl testosterone & $<0.001$ \\
\hline Epitestosterone & 0.1 \\
\hline Ethinylestradiol & $<0.001$ \\
\hline 5a-dihydroandrostenedione & 10 \\
\hline Estradiol 17- $\beta$ & $<0.001$ \\
\hline Cortisol & $<0.001$ \\
\hline progesterone & 0.4 \\
\hline
\end{tabular}

apercentage cross-reaction relative to androstenedione at 50\% binding.

Parallelism between androstenedione standards and endogenous androstenedione in bull plasma

A higher degree of parallelism $(P<0.01)$ was obtained for androstenedione standard curve with serially diluted bull plasma samples containing high concentrations of endogenous androstenedione (Figure 4). A parallel drop was seen in percent binding with increasing plasma volume size and bovine androstenedione standards.

\section{Comparison with RIA}

EIA procedure described above was compared with the values obtained employing the RIA procedure. The concentrations of the hormone obtained by the two methods were very similar and highly correlated (Figure 5).

\section{Conclusions}

In conclusion, we described a specific, sensitive, androstenedione enzyme immunoassay standardized and validated for bovine plasma. The validated androstenedione EIA provides a reliable alternative to RIA. Apart from being non-radioactive in nature, the procedure is safe to perform, cost effective and less time-consuming than the conventional RIA procedures; it can also be adopted in laboratories where financial constraints limit the adoption of RIA.

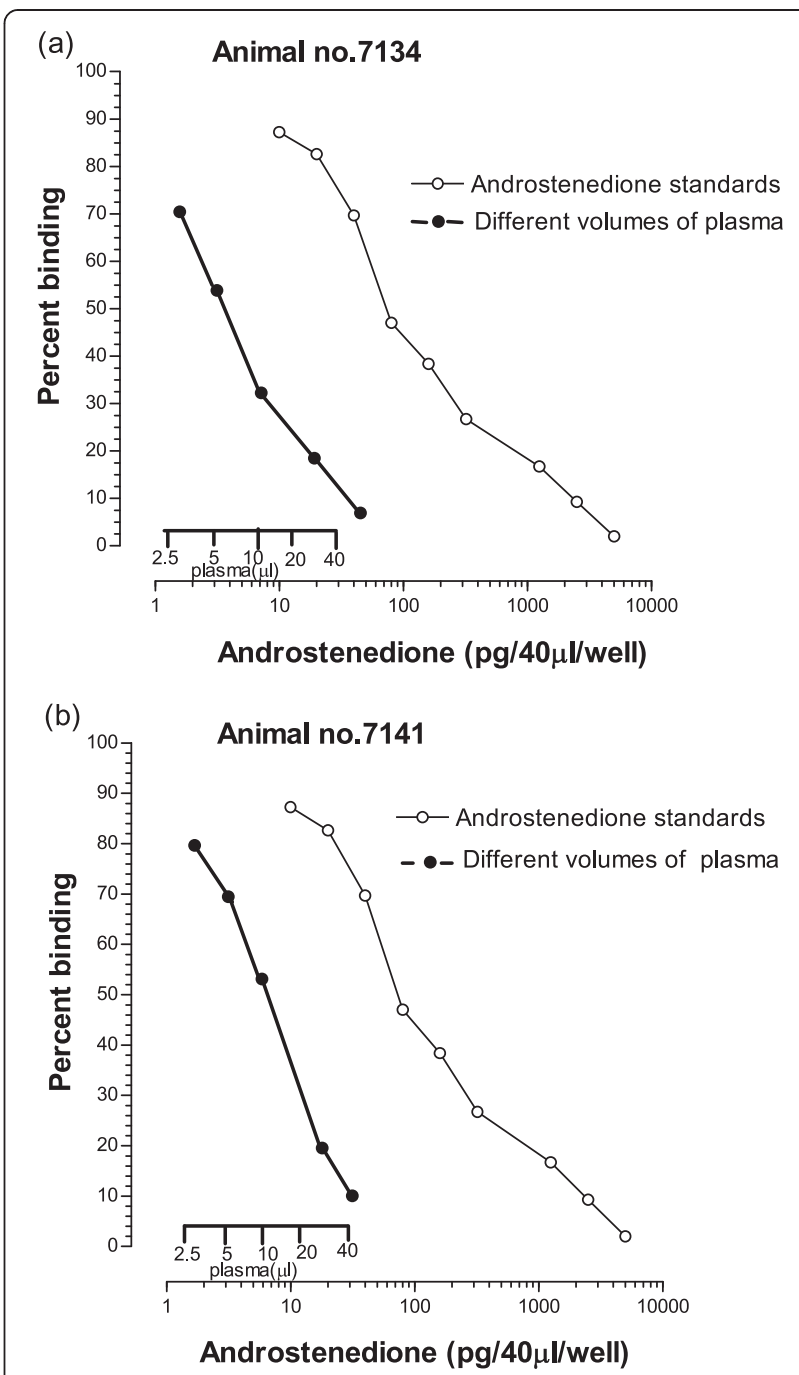

Figure 4 Parallelism for bovine androstenedione standards with serially diluted plasma volumes of Animal no.7134 (a) and Animal no. 7141 (b).

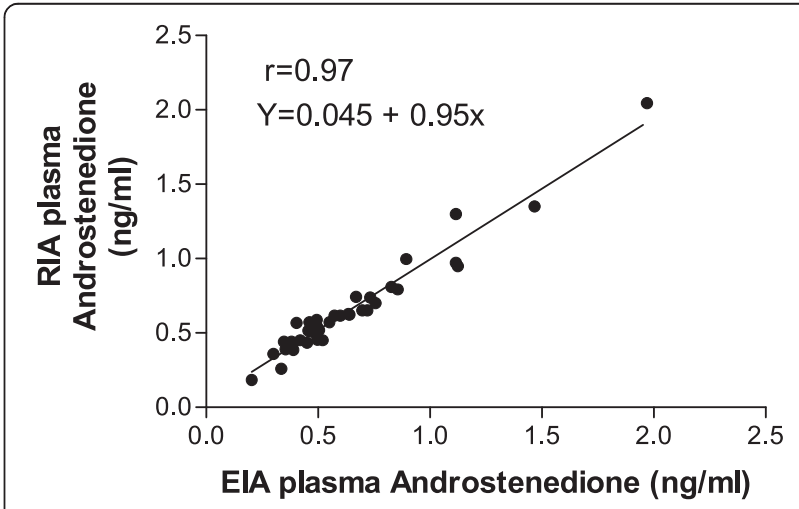

Figure $\mathbf{5}$ Correlation between plasma androstenedione concentrations obtained by RIA and EIA. 


\section{Authors' contributions}

SM and BSBK developed and validated the assay procedure. BSP, AA and SP participated in the design of the study. SM and BSBK performed the statistical analysis. All authors helped to draft the manuscript, and all authors read and approved the final manuscript.

\section{Acknowledgements}

This is a part of the Ph.D. dissertation work of the first author. We extend our gratitude to the Director, National Dairy Research Institute, Karnal, India for providing financial facilities.

\section{Author details}

'Dairy Cattle Physiology Division, National Dairy Research Institute, Karnal 132001, India. ${ }^{2}$ Division of Animal Sciences, Indian Council of Agriculture Research, Krishi Bhavan 10001, New Delhi.

Received: 3 September 2014 Accepted: 11 December 2014 Published online: 05 April 2015

\section{References}

1. Mongkonpunya K, Hafs HD, Convey EM, Tucker HA, Oxender WD. Serum luteinizing hormone, testosterone and androstenedione in pubertal and prepubertal bulls after gonadotropin releasing hormone. J Anim Sci. 1975:40:682-6.

2. Mondain-Monval M, Bonnin M, Scholler R, Canivenc R. Androgens in peripheral blood of the red fox (Vulpes Vulpes L.) during the reproductive season and the anestrous. J Steroid Biochem. 1979;11:1315-22.

3. Cook SJ, Rawlings NC, Kennedy RI. Quantitation of six androgens by combined high performance liquid chromatography and radioimmunoassay. Steroids. 1982;40:369-80.

4. Thorneycroft $I H$, Riberio WO, Stone SC, Tillson SA. A radioimmunoassay of androstenedione. Steroids. 1973;21:111-22.

5. Palme R, Möstl E. Biotin-Streptavidin Enzyme Immunoassay for the Determination of Oestrogens and Androgens in Boar Faeces. In: Görög S, editor. Advances in Steroid Analysis '93. Budapest: Akadémiai Kiadó; 1994. p. 111-7.

6. Illera JC, Silvan G, Munro CJ, Lorenzo PL, Illera MJ, Liu IKM, et al. Amplified androstenedione enzyme immunoassay for the diagnosis of cryptorchidism in the male horse: comparison with testosterone and estrone sulfate methods. J Steroid Biochem Mol Biol. 2003;84:377-82.

7. Ananadlaxmi N, Prakash BS. Production and purification of goat antirabbit IgG. Indian J Dairy Sci. 2001;54:332-4.

8. Liebermann S, Erlanger BF, Beiesr SM, Agate FJ. Steroids-Protein conjugates: their chemical, immunological and endocrinological properties. Prog Horm Res. 1959;15:165-96.

9. Meyer HHD. Possibilities to Improve Enzyme Immunoassay (EIA) Techniques and their Application in Animal Production. In: IAEA and FAO Proceedings of an International Symposium On the use of Nuclear Techniques in Studies of Animal Production and Health in Different Environment. 1986. p. 256-62.

10. Rawlings NC, Hafs HD, Swanson LV. Testicular and blood plasma androgens in Holstein bulls from birth through puberty. J Anim Sci. 1972;34:435-40.

11. Kiser TE, Milvae RA, Hafs HD, Oxender WD, Louis TM. Comparison of testosterone and androstenedione secretion in bulls given prostaglandin F2a or luteinizing hormone. J Anim Sci. 1978;46:436-42.

12. Moura AA, Erickson BH. Age-related changes in peripheral hormone concentrations and their relationships with testis size and number of Sertoli and germ cells in beef bulls. J Reprod Fertil. 1997;111:183-90.

13. Abdel Malak Bedair G, Thibier M. Peripheral plasma androstenedione and testosterone concentrations in bulls before and during puberty. J Reprod Fertil. 1979:56:7-10.

\section{Submit your next manuscript to BioMed Central and take full advantage of:}

- Convenient online submission

- Thorough peer review

- No space constraints or color figure charges

- Immediate publication on acceptance

- Inclusion in PubMed, CAS, Scopus and Google Scholar

- Research which is freely available for redistribution 